\title{
Trends of Macrosomia at University Clinics of Kinshasa
}

\author{
Mbangama-Muela Andy*, Mulumba Kapuku Sylvain, Tozin Rahma Rachid, \\ Lumaya Ambis Joëlle, Tandu-Umba Barthélémy, Mbungu Mwimba Roger, \\ Lokomba Bolamba Vicky, Mbanzulu Pita Damien
}

Department of Obstetrics and Gynaecology, University Clinics, Kinshasa, DR Congo

Email: ^dymuela@yahoo.fr

How to cite this paper: Andy, M.-M., Sylvain, M.K., Rachid, T.R., Joëlle, L.A., Barthélémy, T.-U., Roger, M.M., Vicky, L.B. and Damien, M.P. (2018) Trends of Macrosomia at University Clinics of Kinshasa. Open Journal of Obstetrics and $G y$ necology, 8, 263-272.

https://doi.org/10.4236/ojog.2018.83028

Received: February 23, 2018

Accepted: March 27, 2018

Published: March 30, 2018

Copyright $\odot 2018$ by authors and Scientific Research Publishing Inc. This work is licensed under the Creative Commons Attribution International License (CC BY 4.0).

http://creativecommons.org/licenses/by/4.0/

c) (i) Open Access

\begin{abstract}
Context. The prevalence of macrosomia varies through the world according to racial and ethnic factors, life style and importance of non communicable diseases (maternal obesity, diabetes-gestational and type 2), post-term gestation and multiparity. At the University Clinics of Kinshasa (UCK), 30 years ago, the frequency of macrosomia was $2.4 \%$. Objectives. To update data on the frequency of macrosomia at UCK, regarding variations in maternal anthropometrics (obesity) and socio-demographic factors. Methods. A cross-sectional study was conducted at UCK from 1 January 2007 to 31 December 2016. Mothers who delivered babies weighing at least $4000 \mathrm{~g}$ were included in this study. Results. The frequency of macrosomia was $3.7 \%$. Trend shows a variation of this frequency over time with lowest frequency (2.1\%) in 2012 and highest (5.3\%) in 2009. The mother average age and parity were $32.3 \pm 5.4$ years and $3 \pm 2$, respectively. Pregnancies were complicated by polyhydramnios (48\%) and gestational diabetes (19.7\%). Caesarean section was performed in $60.5 \%$ cases, mainly for macrosomia (47.8\%) and $81.6 \%$ of newborns had constitutional macrosomia. Adverse obstetrical outcomes of macrosomia were dominated by caesarean section (28.9\%), lacerations of birth canal (23\%) and neonatal distress (9.2\%). Conclusion. Macrosomia remains a constant finding at UCK, and is associated with maternal, fetal and neonatal adverse outcomes. Trend shows a variation of the frequency over time between $2.1 \%$ and $5.3 \%$.
\end{abstract}

\section{Keywords}

Macrosomia, Adverse Obstetrical Outcomes, University Clinics of Kinshasa

\section{Introduction}

Macrosomia is defined as a birth weight either greater than $4000 \mathrm{~g}$ or over the 
$90^{\text {th }}$ percentile for gestational age [1]. Its prevalence varies through the world according to racial and ethnic factors, life style and importance of non communicable diseases (maternal obesity, diabetes-gestational and type 2), post-term gestation and multiparity. The variation of prevalence has also been observed in time for the same population [2] [3] [4] [5]. In developed countries, the prevalence of macrosomia, which was between $5 \%$ and $20 \%$ in 1980 increased by $15 \%-25 \%$ in 2007 [2]. In Europe, a Danish study reported an increase in macrosomia incidence from $16.7 \%$ in 1990 to $20 \%$ in 1999 [3]. Figures from North America show that proportion of newborns with a birth weight above 90th percentile increased from 5\% - 9\% in United States and 24\% in Canada between 1985 and 1988 [6]. A Chinese study noted an increase of $6 \%$ in 1994, and 7.8\% in 2005 [4]. In Africa, macrosomia prevalence varies from 1\% to 15\% [7]-[13]. In the Democratic Republic of Congo (DRC), previous studies (30 years ago) estimated its prevalence at $2.4 \%-2.7 \%$ [13] [14]. Since then, no other study addressed this subject. Our study purpose was to update data on frequency of macrosomia at UCK, regarding variation in maternal anthropometrics (obesity) and socio-demographic factors.

\section{Methods}

This cross-sectional study conducted at UCK from 1 January 2007 to 31 December 2016 included all women who delivered babies with macrosomia. All records of pregnant women who gave birth to babies with macrosomia at UCK during study period were included. Files containing less than $50 \%$ of the variables studied were excluded from this study. A total of 8268 births were recorded during this period and 308 babies were born with macrosoma. Data were collected by review of medical records from delivery room and maternity. Variables collected were maternal age, weight, height, body mass index, parity, gravidity, medical history and pregnancy outcomes (obstetrical pathology, gestational age and mode of delivery). Newborns parameters included weight, APGAR, sex, size, head circumference (HC) and thoracic circumference (TC), type of macrosomia defined by ratio of HC to TC (a ratio of $<1$ defining constitutional macrosomia and that $\geq 1$ defining diabetic macrosomia), congenital malformations and neonatal glycemia. Postpartum adverse outcomes (uterine atony, haemorrhage, endometritis, soft tissue lacerations, puerperal infections) were also recorded.

\section{Statistical analysis}

Data were verified, numbered and entered using Microsoft Office Excel software; and then exported to SPSS (Statistical Package for Social Sciences) version 21.0 for appropriate statistical analysis. Quantitative data were summarized as means and standard deviations, and categorical data as frequencies. The study received approval from the ethical board of Department of Obstetrics and Gynecology of UCK.

\section{Results}

In this study we numbered 308 cases of macrosomia out of a total of 8268 delive- 
ries. The frequency was $3.7 \%$. Only 152 files were eligible for study (containing more than $50 \%$ of study variables). Figure 1 shows evolution of annual frequency of macrosomia at UCK since 2007. Trend shows a variation of the frequency over time with lowest frequency (2.1\%) in 2012 and highest (5.3\%) in 2009.

The mean maternal age was $32.3 \pm 5.4$ years, the majority of mothers $(66.4 \%)$ having an age range from 20 to 34 years. The mean parity and gravidity were $3 \pm$ 2. Multipara and multigravida were $80.9 \%$ and $88.8 \%$, respectively. Average maternal weight was $84.7 \pm 15.1 \mathrm{~kg}$, and $53.3 \%$ had less than $90 \mathrm{~kg}$. Mean of Body Mass Index (BMI) was $30.1 \pm 5.1 \mathrm{Kg} / \mathrm{m}^{2}$ and $51.3 \%$ were obese (Table 1 ).

As presented in Table 2, risk factors of macrosomia were dominated by BMI $>25 \mathrm{Kg} / \mathrm{m}^{2}$ (80.9\%), followed by male fetus (58.6\%), maternal overweight (46.7\%) and advanced maternal age (33.6\%).

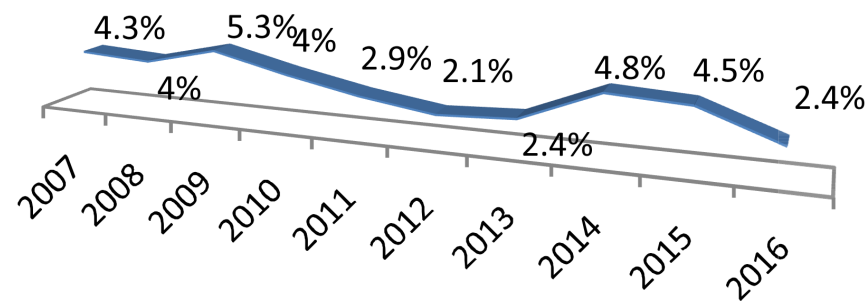

Figure 1. Annual frequency of macrosomia.

Table 1. General maternal characteristics of the study sample.

\begin{tabular}{|c|c|c|}
\hline Parameters & $\mathrm{n}\left(152^{\star}\right)$ & $\%$ \\
\hline \multicolumn{3}{|l|}{ Age range (years) } \\
\hline - $20-34$ & 101 & 66.4 \\
\hline - $\geq 35$ & 51 & 33.6 \\
\hline \multicolumn{3}{|l|}{ Parity } \\
\hline - Primipara (1) & 29 & 19.1 \\
\hline - Multipara ( $\geq 2)$ & 123 & 80.9 \\
\hline \multicolumn{3}{|l|}{ Gravidity } \\
\hline - Primigravida (1) & 17 & 11.2 \\
\hline - Multigravida ( $\geq 2)$ & 135 & 88.8 \\
\hline \multicolumn{3}{|l|}{ Weight (Kg) } \\
\hline - $<90$ & 81 & 53.3 \\
\hline - $\geq 90$ & 71 & 46.7 \\
\hline \multicolumn{3}{|l|}{ BMI $\left(\mathrm{Kg} / \mathrm{m}^{2}\right)$} \\
\hline - Normal (18 - 24) & 29 & 19.1 \\
\hline - Overweight (25 - 29) & 45 & 29.6 \\
\hline - Obesity $(\geq 30)$ & 78 & 51.3 \\
\hline
\end{tabular}

BMI: Body mass index, ${ }^{*}$ Only 152 files were eligible for this study. 
Table 2. Risk factors of macrosomia.

\begin{tabular}{ccc}
\hline Risk factors & n (152) & $\%$ \\
\hline BMI $\geq 25 \mathrm{Kg} / \mathrm{m}^{2}$ & 123 & 80.9 \\
Male sex of fetus & 89 & 58.6 \\
Maternal overweight $(\geq 90 \mathrm{Kg})$ & 71 & 46.7 \\
Maternel age $\geq 35$ ans & 51 & 33.6 \\
Multiparity & 49 & 32.2 \\
Previous macrosomia & 41 & 27 \\
Gestational diabetes & 30 & 19.7 \\
Previous miscarriage & 23 & 15.1 \\
Family diabetes type 2 & 22 & 14.5 \\
Previous stillbirth & 7 & 4.6 \\
Personal diabetes type 2 & 4 & 2.6 \\
Previous hydramnios & 4 & 2.6 \\
Previous fetal malformation & 1 & 0.7 \\
\hline
\end{tabular}

BMI: Body Mass Index.

Concerning delivery characteristics, mean gestational age was $39.4 \pm 1.6$ weeks, mean uterine fundal-height at the admission in the delivery room was $36.7 \pm 2.6 \mathrm{~cm}$ and $98.7 \%$ of deliveries occurred at term and in $60.5 \%$ of cases by Caesarean section. Table 3 shows that C-section was performed in $47.8 \%$ for fetal macrosomia.

Average APGAR score was $8 \pm 2$ at birth, and $9 \pm 1$ at the fifth minute. Table 4 shows that $90.8 \%$ of newborns had a good APGAR score at birth and $92.1 \%$ at the fifth minute. The means of birth weight, height, head and thoracic circumferences were $4235.2 \pm 314.2 \mathrm{~g}, 51.8 \pm 1.9 \mathrm{~cm}, 36.5 \pm 2.1 \mathrm{~cm}$ and $35.2 \pm 1.7 \mathrm{~cm}$, respectively. Male newborns represented $58.6 \%$ of newborns, with a sex ratio of 0.77 . In $81.6 \%$ of cases, macrosomia was constitutional.

Maternal and perinatal adverse outcomes associated with macrosomia, presented in Table 5, were dominated, on maternal side, by Caesarean section (28.9\%) and lacerations of birth canal (23\%), and neonatal distress on perinatal side $(9.2 \%)$.

\section{Discussion}

In the present study, the frequency of macrosomia at UCK was $3.7 \%$, higher than that $(2.7 \%)$ reported 30 years ago [13] [14]. This could be owed to changes in maternal BMI [15]. Trend showing a variation of this frequency over time between $5.3 \%$ in 2009 and $2.1 \%$ in 2012 is difficult to explain. This frequency is slightly lower than 5.6\%,5.7\%,6.6\% and 7\% as reported in Saudi Arabia [16], in Lubumbashi (DRC) [17], in France [18] and in Turkey [19], respectively. It's higher than those reported in some other studies in Africa by Badji et al. [20], in 
Table 3. Indications of cesarean section.

\begin{tabular}{lcc}
\hline \multicolumn{1}{c}{ Indications } & n (92) & $\%$ \\
\hline - Macrosomia & 44 & 47.8 \\
- Uterine scar & 12 & 13 \\
- Fetal malposition & 10 & 10.9 \\
- Acute fetal distress & 9 & 9.8 \\
- Fetal-pelvic Disproportion & 9 & 9.8 \\
- Severe chronic fetal distress & 3 & 3.3 \\
- Narrowed pelvis & 2 & 2.2 \\
- Severe preeclampsia & 2 & 2.2 \\
\hline
\end{tabular}

Table 4. Newborn characteristics.

\begin{tabular}{|c|c|c|}
\hline Parameters & n (152) & $\%$ \\
\hline \multicolumn{3}{|c|}{ APGAR score at the first minute } \\
\hline$\bullet 0$ & 2 & 1.3 \\
\hline - $1-3$ & 2 & 1.3 \\
\hline - $4-6$ & 10 & 6.6 \\
\hline - $\geq 7$ & 138 & 90.8 \\
\hline \multicolumn{3}{|c|}{ APGAR score at the fifth minute } \\
\hline$\bullet 0$ & 2 & 1.3 \\
\hline - $1-3$ & 2 & 1.3 \\
\hline - $4-6$ & 8 & 5.3 \\
\hline$\bullet \geq 7$ & 140 & 92.1 \\
\hline \multicolumn{3}{|l|}{ Newborn's sex } \\
\hline - Male & 89 & 58.6 \\
\hline - Female & 63 & 41.4 \\
\hline \multicolumn{3}{|c|}{ Type of macrosomia (HC/TC) } \\
\hline - Constitutional & 124 & 81.6 \\
\hline - Diabetic & 28 & 18.4 \\
\hline
\end{tabular}

HC: head circumference, TC: Thoracic circumference.

Table 5. Adverse outcomes of macrosomia.

\begin{tabular}{lcc}
\hline & n (152) & $\%$ \\
\hline Maternal outcomes & & \\
- Cesarean section & 44 & 28.9 \\
- Lacerations of birth canal & 35 & 23 \\
- Postpartum hemorrhage & 9 & 5.9 \\
- Uterine atony & 4 & 2.6 \\
- Premature labor & 1 & 0.7 \\
\hline
\end{tabular}


Perinatal outcomes

- Neonatal distress

$\begin{array}{ll}14 & 9.2 \\ 2 & 1.3 \\ 2 & 1.3 \\ 2 & 1.3 \\ 1 & 0.7\end{array}$

Senegal, by Thieba et al. [21], in Burkina-Faso and by Kakudji et al. [12], in Kinshasa (DRC) and also by Cheng et al. [5], in China who reported $1.57 \%$, $2.1 \%, 2.4 \%$ and $3.4 \%$ respectively. However, our frequency is very lower than those reported by Ananth et al. [6], in Canada (24\%) between 1992 and 1996 and by Jensen et al. [22] in Denmark (28\%).

Our results are in accordance with literature data which show variation of incidence according to racial and ethnic differences but also with presence of local factors in different regions [2]. The lower frequency reported by Cheng et al. [23], could be explained by the difference in birth weight distribution probably due to genetic differences and anthropometric disparities between populations. The lower frequency reported in african studies could principally be explained by nutritional insufficiency and lower socio-economic level.

Macrosomia in our study was mostly observed in mothers with BMI $\geq 25$ $\mathrm{Kg} / \mathrm{m}^{2}(80.9 \%)$, with maternal weight $\geq 90 \mathrm{Kg}$ (46.7\%). Several studies have reported higher frequencies of macrosomia in obese women [24] [25] [26], and Henriksen [2], found BMI as independent factor of macrosomia. The combination of maternal-transmitted fetal hyperglycemia and fetal hyperinsulinism could explain the high rate of macrosomia in newborns of obese non-diabetic mothers [9].

Concerning newborns gender, 58.6\% were male, a finding also reported in Lubumbashi [13] [17], Rabat [25], and Brazzaville [27], where it was reported a frequency of male newborn above $60 \%$. This is in accordance with the role of male hormones.

In our study, $80.9 \%$ of mothers were multipara. Studies have shown that multiparity is a factor that increases risk of macrosomia, irrespective of its association with maternal age. Our results corroborate those of most authors [7] [9] [11] [17] [19] [27]. This finding could be the expression of obesity or diabetes whose risk increases with age. Advanced maternal age ( $\geq 35$ years) and multiparity were associated with fetal macrosomia in our series (33.6\% and $32.2 \%$ respectively).

In this study, pregnant women also had a family history of diabetes type 2 (14.5\%) or developed gestational diabetes during pregnancy (19.7\%). Das et al. [28] and Saleh et al. [16] reported that diabetes, regardless of its clinical form (type 2 or gestational), is an important factor involved in risk of macrosomia. This is in accordance whith diabetes and obesity as well known risk factors of macrosomia. Our results are consistent with those of several authors [17] [19] 
[28] [29] [30]. The mechanism, reported in literature, to explain this association is interdependence of metabolism of carbohydrates and lipids, resulting in fetal hyperinsulinism reaction to maternal hyperglycemia. Increased production of insulin, an anabolic hormone, forces carbohydrates into cells, accumulates fatty acids in adipose tissue and proteins in muscles, which is responsible for the onset of macrosomia [17] [31] [32]. Macrosomia was associated with maternal and perinatal adverse outcomes. Higher risks of infant mortality and traumatic injuries during childbirth have also been reported by Zhang et al. [33], for macrosome neonates with a birth weight greater than $4.500 \mathrm{~g}$. Heiskanen [34], particularly cited clavicle or humerus fractures, brachial or facial paralysis, and shoulder dystocia. The most common complications of macrosomia in our study were Cesarean section (28.9\%) and soft tissue injuries (23\%), while for newborn, it was perpartal distress (9.2\%). Chauhan et al. [35] and Zhang et al. [33], also reported maternal adverse outcomes associated with fetal macrosomia, including prolonged labor, cesarean section and postpartum hemorrhage.

Further research must be focused on the recognition of risk factors during the antenatal visit care and its prevention in the aim to reduce its incidence and thus the related complications.

The main limitation of this study could be found in the fact that it concerned only one site (monocentric study), which limits extrapolation of results.

\section{Conclusion}

Macrosomia remains a constant finding at UCK, and is associated with maternal, fetal and neonatal adverse outcomes. Trend shows a variation of this frequency over time between $2.1 \%$ and $5.3 \%$.

\section{Author Contributions}

All authors contributed toward data analysis, drafting and revising the paper and agree to be accountable for all aspects of the work.

\section{Disclosure}

The authors report no conflict of interest in this work.

\section{References}

[1] La Vallie, D.L., Gabbe, S.G., Grossman, D.C., Larson, E.B., Baldwin, L.M. and Andrilla, C.H. (2003) Birth Outcomes among American Indian/Alaska Native Women with Diabetes in Pregnancy. The Journal of Reproductive Medicine, 48, 610-616.

[2] Henriksen, T. (2008) The Macrosomic Fetus: A Challenge in Current Obstetrics. Acta Obstetricia et Gynecologica Scandinavica, 87, 134-145. https://doi.org/10.1080/00016340801899289

[3] Ørskou, J., Kesmodel, U., Henriksen, T.B. and Secher, N.J. (2001) An Increasing Proportion of Infants Weigh more than 4000 Grams at Birth. Acta Obstetricia et Gynecologica Scandinavica, 80, 931-936. https://doi.org/10.1034/j.1600-0412.2001.801010.x 
[4] Lu ,Y., Zhang, J., Lu, X., Xi, W. and Li, Z. (2011) Secular Trends of Macrosomia in Southeast China, 1994-2005. BMC Public Health, 11, 818. https://doi.org/10.1186/1471-2458-11-818

[5] Cheng, Y.K., Lao, T.T., Sahota, D.S., Leung, V.K. and Leung, T.Y. (2013) Use of Birth Weight Threshold for Macrosomia to Identify Fetuses at Risk of Shoulder Dystocia among Chinese Populations. International Journal of Gynecology \& $O b$ stetrics, 120, 249-253. https://doi.org/10.1016/j.ijgo.2012.10.019

[6] Ananth, C.V. and Wen, S.W. (2002) Trends in Fetal Growth among Singleton Gestations in the United States and Canada, 1985 through 1998. Seminars in Perinatology, 26, 260-267. https://doi.org/10.1053/sper.2002.34772

[7] Ezegwui, H.U., Ikeako, L.C. and Egbuji, C. (2011) Fetal Macrosomia: Obstetric Outcome of 311 Cases in UNTH, Enugu, Nigeria. Nigerian Journal of Clinical Practice, 14, 322-326. https://doi.org/10.4103/1119-3077.86777

[8] AbdelBagi, A. and Ahmed, M. (2015) Macrosomia at Medani Hospital, Sudan. Journal of Science, 4, 718-720.

[9] EL Bakkali, M., Azzouzi, Y., Khadmaoui, A., Thami Ahami, A.O. and EL Khlifi, F. (2014) Les facteurs associés a la survenue de la macrosomie chez le nouveau-né à l'Hôpital Régional Cherif Idrissi dans la région du Gharb au Maroc. ESJ, 10, 11-22.

[10] Mai, A.H. and Abbassia, D. (2014) The Prevalence of Fetal Macrosomia at the Specialized Hospital of Gynecology and Obstetrics of Sidi Bel Abbes (West of Algeria). Journal of Nutrition and Food Sciences, 4, 272.

[11] Koyanagi, A., Zhang, J., Dagvadorj, A., Hirayama, F., Shibuya, K., Souza, J.P. and Gulmezoglu, A.M. (2013) Macrosomia in 23 Developing Countries: An Analysis of a Multicountry, Facility-Based, Cross-Sectional Survey. The Lancet, 381, 476-483. https://doi.org/10.1016/S0140-6736(12)61605-5

[12] Ye, J., Torloni, M.R., Ota, E., Jayaratne, K., Pileggi-Castro, C., Ortiz-Panozo, E. Lumbiganon, P., Morisaki, N., Laopaiboon, M., Mori, R., Tunçalp, Ö., Fang, F., Yu, H., Souza, J.P., Vogel, J.P. and Zhang, J. (2015) Searching for the Definition of Macrosomia through an Outcome-Based Approach in Low- and Middle-Income Countries: A Secondary Analysis of the WHO Global Survey in Africa, Asia and Latin America. BMC Pregnancy Childbirth, 15, 324.

https://doi.org/10.1186/s12884-015-0765-Z

[13] Kakudji, L., Mvuezolo, B., Tandu-Umba, N.F.B., Mputu, L. and Yanga, K. (1984) Aspects cliniques et obstétricaux des accouchements des gros enfants en milieu zaïrois. Annals of African Medicine, 23, 99-102.

[14] Mulende, K. (2003) Accouchement des macrosomes aux Cliniques Universitaires de Kinshasa du 01/01/1994 au 31/12/2000. Mémoire de Spécialisation en Gynécologie et Obstétrique, Université de Kinshasa.

[15] Mbangama, M.A. and Tandu-Umba, B. (2014) Etat nutritionnel gravidique à terme et risque de diabète gestationnel. Diabetes Research and Clinical Practice, 103, S50. https://doi.org/10.1016/S0168-8227(14)70165-2

[16] Saleh, A.M., Al-Sultan, S.M., Moria, A.M., Rakaf, F.I., Turkistani, Y.M. and Al-Onazi, S.H. (2008) Fetal Macrosomia Greater than or Equal to 4000 Grams: Comparing Maternal and Neonatal Outcomes in Diabetic and Nondiabetic Women. Saudi Medical Journal, 29, 1463-1469.

[17] Kakudji, L.P., Mukuku, O., Mubinda, K.P., Mwembo, A.T. and Kalenga, M.K.P. (2016) Macrosomie fotale à Lubumbashi: Facteurs de risque et pronostic maternel et périnatal. Pan African Medical Journal, 23, 166. 
[18] Fuchs, F., Bouyer, J., Rozenberg, P. and Senat, M.V. (2013) Adverse Maternal Outcomes Associated with Fetal Macrosomia: What Are the Risk Factors beyond Birthweight? BMC Pregnancy Childbirth, 13, 90. https://doi.org/10.1186/1471-2393-13-90

[19] Akín, Y., Cömert, S., Turan, C., Píçak, A., Agzíkuru, T. and Telatar, B. (2010) Macrosomic Newborns: A 3-Year Review. The Turkish Journal of Pediatrics, 52, 378-383.

[20] Badji, C.A., Moreau, J.C., Ba, M.G., Diallo, D., Diouf, A., Dotou, C., Tahri, L. and Diadhiou, F. (1999) L'accouchement du gros enfant au CHU de Dakar: Epidémiologie et pronostic. Medecine d'Afrique Noire, 46, 355-358.

[21] Thieba, B., Akontionga, M., Ouedraogo, A., Kaba, T., Ouattara, T., Lankouande, J. and Kone, B. (2004) Gros fotus: Pronostic materno-fœtal à propos de 143 cas à la maternité du centre hospitalier universitaire de Ouagadougou. Journal de la $S A G O$, 5, 22-28.

[22] Jensen, D.M., Damm, P., Sorensen, B., Molsted-Pedersen, L., Westergaard, J.G., Klebe, J. and Beck-Nielsen, H. (2001) Clinical Impact of Mild Carbohydrate Intolerance in Pregnancy: A Study of 2904 Nondiabetic Danish Women with Risk Factors for Gestational Diabetes Mellitus. American Journal of Obstetrics \& Gynecology, 185, 413-419. https://doi.org/10.1067/mob.2001.115864

[23] Cheng, Y.K.Y. and Lao, T.T. (2014) Fetal and Maternal Complications in Macrosomic Pregnancies. Research and Reports in Neonatology, 4, 65-70.

[24] Cedergren, M.I. (2004) Maternal Morbid Obesity and the Risk of Adverse Pregnancy Outcome. Obstetrics \& Gynecology, 103, 219-224. https://doi.org/10.1097/01.AOG.0000107291.46159.00

[25] Weiss, J.L., Malone, F.D., Emig, D., Ball, R.H., Nyberg, D.A., Comstock, C.H., Saade, G., Eddleman, K., Carter, S.M., Craigo, S.D., Carr, S.R. and D'Alton, M.E. (2004) Obesity, Obstetric Complications and Caesarean Delivery Rate-A Population-Based Screening Study. American Journal of Obstetrics \& Gynecology, 190, 1091-1097. https://doi.org/10.1016/j.ajog.2003.09.058

[26] Touhami Elouazzani, F., Kabiri, M., Karboubi, L., Keswati, J., Mrabet, M. and Barkat, A. (2012) La macrosomie: A propos de 255 cas. Journal de Pediatrie et de Puériculture, 25, 97-101. https://doi.org/10.1016/j.jpp.2011.12.003

[27] Iloki, L.H., Itoua, C., Mbemba Moutounou, G.M., Massouama, R. and Koko, P.S. (2014) Macrosomie fœtale: Facteurs de risque et complications materno-fœtales à Brazzaville (République du Congo). Médecine d'Afrique Noire, 61, 479-486.

[28] Das, S., Irigoyen, M., Patterson, M.B., Salvador, A. and Schutzman, D.L. (2009) Neonatal Outcomes of Macrosomic Births in Diabetic and Non-Diabetic Women. BMJ Journals, 94, 419-422. https://doi.org/10.1136/adc.2008.156026

[29] Yazdani, S., Yosofniyapasha, Y., Nasab, B.H., Mojaveri, M.H. and Bouzari, Z. (2012) Effect of Maternal Body Mass Index on Pregnancy Outcome and Newborn Weight. BMC Research Notes, 5, 34. https://doi.org/10.1186/1756-0500-5-34

[30] Mochhoury, L., Razine, R., Kasouati, J., Kabiri, M. and Barkat, A. (2013) Body Mass Index, Gestational Weight Gain, and Obstetric Complications in Moroccan Population. Journal of Pregnancy, 2013, Article ID: 379461.

https://doi.org/10.1155/2013/379461

[31] Lepercq, J., Timsit, J. and Hauguel-de Mouzon, S. (2000) Etiopathogénie de la macrosomie fœtale. Journal de Gynécologie Obstétrique et Biologie de la Reproduction, 29, 6-12. 
[32] Sacks, D.A. (2007) Etiology, Detection and Management of Fetal Macrosomia in Pregnancies Complicated by Diabetes Mellitus. Clinical Obstetrics and Gynecology, 50, 980-989. https://doi.org/10.1097/GRF.0b013e31815a6242

[33] Zhang, X., Decker, A., Platt, R.W. and Kramer, M.S. (2008) How Big Is Too Big? The Perinatal Consequences of Fetal Macrosomia. American Journal of Obstetrics \& Gynecology, 198, 517.e1-517.e6. https://doi.org/10.1016/j.ajog.2007.12.005

[34] Heiskanen, N., Raatikainen, K. and Heinonen, S. (2006) Fetal Macrosomia: A Continuing Obstetric Challenge. Biology of the Neonate, 90, 98-103. https://doi.org/10.1159/000092042

[35] Chauhan, S.P., Grobman, W., Gherman, R.A., Chauhan, V.B., Chang, G., Magann, E.F. and Hendrix, N.W. (2005) Suspicion and Treatment of the Macrosomic Fetus: A Review. American Journal of Obstetrics \& Gynecology, 193, 332-346. https://doi.org/10.1016/j.ajog.2004.12.020 